\title{
ANALISIS PEMBERDAYAAN PETANI BAWANG MERAH MELALUI PMUK (PENGUATAN MODAL USAHA KELOMPOK) DI DESA CEUROCOK SAGOE KECAMATAN SIMPANG TIGA KABUPATEN PIDIE
}

\author{
Cut Risma Aini1, dan Nurul Samiah2
}

Program Studi Agribisnis Fakultas Pertanian

Universitas Jabal Ghafur

\begin{abstract}
Penelitian ini bertujuan menganalisis kegiatan pemberdayaan petani melalui program PUMK (Penguatan Modal Usaha Kelompok) dan peranannya terhadap peningkatan pendapan petani melalui program PUMK (Penguatan Modal Usaha Kelompok) di Ceurucok Sagoe Keamatan Simpang Tiga Kabupaten Pidie. Penelitian dilakukan pada bulan anuari 2017. Populasi penelitian adalah seluruh petani yang terlibat dalam kegiatan pemberdayaan petani Bawang Merah melalui PUMK (Penguatan Modal Usaha Kelompok) yang berumlah 180 Petani, sampel yang diambil sebanyak 36 Petani. Metode analisis data mengunakan regresi linear sederhana.

Program PMUK mempunyai pengaruh signifikan terhadap pemberdayaan petani Bawang Merah di Desa Ceurucok Sagoe Kecamatan Simpang Tiga Kabupaten Pidie dengan koefisien variabl sebesar 0,964 atau pelaksanaan program PUMK sebesar satuan akan meningkatkan pemberdayaan petani sebesar 0,964 satuan. Koefisien determinasi sebesar 0,528 menunjukkan variable PMUK dapt menelaskan variable pemberdayaan petani sebesar $52,80 \%$. Nilai t hitung $>\mathrm{t}$ tabel $(6,17>, 028)$ dengan (tingkat kepercayaan $95 \%$ ), artinya variable PMUK mempunyai pengaruh yang siginifikan terhadap peningkatan pemberdayaan petani Bawang Merah di Desa Ceurucok Sagoe Kecamatan Simpang Tiga Kabupaten Pidie
\end{abstract}

Kata Kunci : Analisis, Pemberdayaan, Petani, Bawang Merah, PUMK (Penguatan Modal Usaha Kelompok)

\section{PENDAHULUAN \\ Latar Belakang}

Bawang merah merupakan salah satu komoditas sayuran unggulan yang sejak lama telah diusahakan oleh petani secara intensif. Komoditas sayuran ini termasuk ke dalam kelompok rempah tidak bersubstitusi yang berfungsi sebagai bumbu penyedap makanan serta bahan obat tradisional.

Pada periode 2010-2014, produksi bawang merah nasional mengalami peningkatan sebesar $5,74 \%$ per tahun, dimana pada tahun 2010 produksinya sebesar 1,05 juta ton kemudian pada tahun 2014 menjadi 1,23 juta ton. Peningkatan produksi tersebut disebabkan oleh meningkatnya luas panen sebesar 3,70\% per tahun dan produktivitas naik sebesar 2,00\% per tahun. Pada tahun 2016, produksi bawang merah diperkirakan naik sebesar $2,91 \%$ dan terus akan naik hingga tahun 2019. Tahun 2019, produksi bawang merah diperkirakan akan mencapai 1,31 juta ton dengan rata-rata pertumbuhan $1,24 \%$ per tahun.

Sementara di Provinsi Aceh, produksi bawang merah pada tahun 2014 sebesar 67,06 ribu kuintal, mengalami peningkatan 29,96 kuintal (80,73\%) dibandingan pada tahun 2013. Peningkatan produksi tersebut disebabkan meningkatnya luas panen di Kabupaten Pidie sebesar 204 hektar atau sebesar 221,74\% dan Kabupaten Aceh Tengah sebesar 128 hektar atau sebesar $142,22 \%$. Produksi dan luas panen bawang merah pada tahun 2014 di Kabupaten Pidie sebesar 29,49 ribu kuintal dan 296 hektar dengan produktivitas sebesar 99,63 kuintal per hektar. Data produksi dan produktivitas tanaman bawang merah di Kabupaten Pidie tahun 2012-2014 dapat dilihat pada Tabel 1.

Tabel 1. Produksi dan Produktivitas Tanaman Bawang Merah di Kabupaten Pidie, Tahun 2012 $-2014$

\begin{tabular}{|c|c|c|c|c|}
\hline Tahun & $\begin{array}{c}\text { Produksi } \\
(\mathrm{kw})\end{array}$ & $\begin{array}{c}\text { Pertumbuhan } \\
(\%)\end{array}$ & $\begin{array}{c}\text { Produktivitas } \\
(\mathrm{kw} / \mathrm{ha})\end{array}$ & $\begin{array}{c}\text { Pertumbuhan } \\
(\%)\end{array}$ \\
\hline 2012 & 12.321 & - & 60,40 & - \\
\hline 2013 & 5.802 & 52,91 & 63,07 & 4,42 \\
\hline 2014 & 29.490 & 408,27 & 99,63 & 57,98 \\
\hline
\end{tabular}

Sumber: BPS Provinsi Aceh, aceh.bps.go.id, 2015. 
Salah satu peran pemerintah dalam upaya mencapai target pengembangan mutu produk bawang merah dilakukan dengan memfasilitasi masyarakat tani melalui Program Penguatan Modal Usaha Kelompok (PMUK). Kegiatan PMUK terutama bertujuan untuk meningkatkan permodalan kelompok tani sehingga petani dapat meningkatkan kegiatan ekonomi dan pendapatannya. Selain itu, dengan terpenuhinya modal usaha maka adopsi inovasi teknologi di tingkat usaha tani dapat berkelanjutan. Pola pemberdayaan dilakukan guna mengatasi masalah utama di tingkat usahatani yaitu keterbatasan modal petani, di samping masalah belum berkembangnya usaha di hulu, hilir dan jasa penunjang dalam pembangunan pertanian, rendahnya penguasaan teknologi serta lemahnya SDM dan kelembagaan petani.

Desa Ceurucok Sagoe Kecamatan Simpang Tiga Kabupaten Pidie merupakan salah satu desa penerima bantuan PMUK melalui kelompok tani yang ada di desa tersebut. Selama ini, petani menghadapi kendala penyediaan modal bagi keberlangsungan usahatani bawang merah, mengingat harga bibit dan sarana produksi yang mahal. Keterbatasan modal yang dihadapi petani mengakibatkan sulitnya menerapkan teknologi usahatani dalam rangka meningkatkan produksi dan mengembangkan skala usaha.

Berdasarkan uraian tersebut penulis melakukan penelitian dengan judul: "Analisis Pemberdayaan Petani Bawang Merah melalui PMUK (Penguatan Modal Usaha Kelompok) di Desa Ceurucok Sagoe Kecamatan Simpang Tiga Kabupaten Pidie".

\section{Perumusan Masalah}

Berdasarkan latar belakang diatas maka rumusan masalah dalam penelitian ini adalah : Apakah pemberdayaan petani bawang merah melalui Program PMUK (Penguatan Modal Usaha Kelompok) di Desa Ceurucok Sagoe Kecamatan Simpang Tiga sehingga dapat meningkatkan pendapatan petani.

\section{Hipotesis}

PMUK berpengaruh positif terhadap pemberdayaan petani bawang merah dalam meningkatkan pendapatan petani di Desa Ceurucok Sagoe Kecamatan Simpang Tiga Kabupaten Pidie.

\section{Metode Penelitian}

Lokasi penelitian adalah Desa Ceeurecok Sagoe Kecamatan Simpang Tiga Kabupaten Pidie. Lokasi dipilih secara sengaja (purposive) dengan pertimbangan bahwa daerah tersebut merupakan salah satu sentra produksi Bawang Merah di Kecamatan Simpang Tiga di Kabupaten Pidie. Penelitian dilakukan pada bulan Januari 2017.

Populasi penelitian adalah seluruh petani yang terlibat dalam kegiatan pemberdayaan petani bawang merah melalui PMUK (Penguatan Modal Usaha Kelompok) di Desa Ceurucok Sagoe Kecamatan Simpang Tiga. Jumlah kelompok tani peserta binaan yang mendapatkan fasilitas PMUK dengan pola BPLM sebanyak 18 kelompok tani, dengan jumlah anggota sebanyak 10 orang per kelompok atau secara keseluruhan terdapat 180 petani. Dari masing-masing kelompok tani diambil 2 petani sebagai sampel dengan cara random sampling (acak sederhana). Dengan demikian jumlah sampel dalam penelitian ini adalah 36 petani penerima PMUK.

Alat analisis yang digunakan untuk menguji hipotesis yang telah dikemukakan mengenai pemberdayaan petani bawang merah melalui PMUK digunakan persamaan regresi linear sederhana sebagai berikut:

$$
\mathrm{Y}=\mathrm{a}+\mathrm{bX}+\mathrm{e}
$$

(Indriantoro dan Supomo, 2003)

Dimana :

$\mathrm{Y} \quad=$ Pemberdayaan petani bawang merah

$$
\mathrm{X}=\text { PMUK }
$$

$\mathrm{a}=$ Konstanta

$\mathrm{b}=$ Koefisien variabel PMUK

Untuk menguji pengaruh dari variabel bebas (PMUK) terhadap variabel terikat (pemberdayaan masyarakat dilakukan dengan menggunakan uji t) sebagai berikut:

$$
\text { thitung }=\frac{\mathrm{B}}{\mathrm{Se}(\mathrm{b})}
$$

\section{HASIL DAN PEMBAHASAN \\ Pelaksanaan Program Penguatan Modal Usaha Kelompok (PMUK)}

Proses pencairan dana PMUK yaitu diawali dengan penyusunan Rencana Usaha Anggota (RUA) yang memuat secara spesifik tentang luas lahan, kebutuhan bibit, pupuk dan pestisida. Selanjutnya, RUA direkapitulasi di tingkat kelompok menjadi Rencana Usaha Kelompok (RUK). RUK memuat nama-nama 
anggota kelompok, luas lahan dan jumlah dana yang akan dipinjam. Selanjutnya, pendistribusian dana dilakukan melalui kelompok tani masing-masing, dimana petani tercatat sebagai anggotanya. Mekanisme pengembalian pinjaman yaitu sesudah panen dengan besar pengembalian pinjaman yaitu pinjaman pokok ditambah jasa yang telah disepakati bersama melalui musyawarah kelompok.

Pelaksanaan program PMUK di Desa Ceurucok Sagoe didasarkan pada lima indikator peran yaitu: (1) meningkatnya produksi bawang merah; (2) peningkatan produktivitas tanaman; (3) pelaksanaan pengembalian pinjaman tepat waktu; (4) penerapan sanksi bagi anggota yang tidak mengembalikan pinjaman; dan (5) peningkatan skala usahatani bawang merah. Rekapitulasi jawaban responden tentang kelima indikator tersebut dapat dilihat pada tabel berikut.

Tabel 9. Rekapitulasi Jawaban Responden tentang Pelaksanaan Program PMUK

\begin{tabular}{|c|c|c|c|c|c|c|c|}
\hline No & Pertanyaan & SS & $\mathrm{S}$ & $\mathrm{R}$ & TS & STS & $\begin{array}{l}\text { Rata- } \\
\text { Rata }\end{array}$ \\
\hline 1 & $\begin{array}{l}\text { Sejak adanya } \\
\text { bantuan PMUK } \\
\text { produksi bawang } \\
\text { merah meningkat }\end{array}$ & $8(40)$ & $\begin{array}{c}27 \\
(108)\end{array}$ & $\begin{array}{l}1 \\
\text { (3) }\end{array}$ & & & 4,19 \\
\hline 2 & $\begin{array}{l}\text { PMUK telah } \\
\text { meningkatkan } \\
\text { produktivitas } \\
\text { tanaman bawang } \\
\text { merah yyang } \\
\text { dikelola }\end{array}$ & $\begin{array}{c}10 \\
(50)\end{array}$ & $\begin{array}{c}24 \\
(96)\end{array}$ & $\begin{array}{l}2 \\
\text { (6) }\end{array}$ & & & 4,22 \\
\hline 3 & $\begin{array}{l}\text { Saya } \\
\text { mengembalikan } \\
\text { pinjaman modal } \\
\text { PMUK ke kas } \\
\text { kelompok tani tepat } \\
\text { waktu }\end{array}$ & $7(35)$ & $\begin{array}{c}17 \\
(68)\end{array}$ & $\begin{array}{c}12 \\
(36)\end{array}$ & & & 3,86 \\
\hline 4 & $\begin{array}{l}\text { Anggota kelompok } \\
\text { tani yang tidak } \\
\text { mengembalikan } \\
\text { pinjaman modal } \\
\text { bantuan PMUK } \\
\text { tidak } \\
\text { diperkenankan } \\
\text { kembali meminjam }\end{array}$ & $7(35)$ & $\begin{array}{c}23 \\
(92)\end{array}$ & $\begin{array}{c}6 \\
(18)\end{array}$ & & & 4,03 \\
\hline 5 & $\begin{array}{l}\text { Skala usahatani } \\
\text { meningkat setelah } \\
\text { memperoleh } \\
\text { bantuan modal } \\
\text { PMUK }\end{array}$ & $\begin{array}{c}23 \\
(115)\end{array}$ & $6(24)$ & $\begin{array}{c}7 \\
\text { (21) }\end{array}$ & & & 4,44 \\
\hline
\end{tabular}

Sumber: data primer, diolah, 2017.

Pada tabel di atas dapat dijelaskan bahwa indikator pertama, produksi bawang merah meningkat sejak adanya program PMUK. Jawaban responden sebanyak 8 responden menjawab sangat setuju, 27 responden menjawab setuju, 1 responden menjawab raguragu, dan tidak ada responden menjawab tidak setuju dan sangat tidak setuju. Nilai skor ratarata diperoleh sebesar 4,19 berarti responden setuju dengan pelaksanaan program PMUK dapat meeningkatan produksi bawang merah. Peningkatan produksi terjadi melalui peningkatan luas lahan dan produktivitas tanaman.

Indikator kedua, PMUK telah meningkatkan produktivitas tanaman bawang merah yang dikelola. Jawaban responden sebanyak 10 responden menjawab sangat setuju, 24 responden menjawab setuju, 2 responden menjawab ragu-ragu dan tidak ada responden yang menjawab tidak setuju dan sangat tidak setuju. Nilai skor rata-rata sebesar 4,22 berarti responden menyatakan setuju bahwa pelaksanaan program PMUK di Desa Ceurucok Sagoe telah meningkatkan produktivitas tanaman bawang merah. Peningkatan produktivitas terjadi melalui perbaikan teknik budidaya yang disampaikan oleh penyuluh selaku tenaga pendamping program PMUK.

Indikator ketiga, pengembalian pinjaman modal PMUK tepat waktu. Jawaban responden sebanyak 7 responden menjawab sangat setuju, 17 responden menjawab setuju, 12 responden menjawab ragu-ragu, dan tidak ada responden yang menjawab tidak setuju dan sangat tidak setuju. Nilai skor rata-rata sebesar 3,86 (hampir mendekati 4 = setuju) artinya sebagian besar responden mengembalikan pinjaman tepat waktu, meskipun ada juga beberapa yang masih menunggak.

Indikator keempat, pemberian sanksi kepada anggota kelompok tani yang tidak mengembalikan pinjaman. Jawaban responden sebanyak 7 responden menjawab sangat setuju, 23 respnden menjawab setuju, 6 responden menjawab ragu-ragu, dan tidak ada responden yang menjawab tidak setuju dan sangat tidak setuju. Nilai skor rata-rata sebesar 4,03 , yang berarti responden setuju pemberian sanksi kepada anggota yang tidak melunasi pinjaman dana PMUK.

Indikator kelima, PMUK telah meningkatkan skala usahatani bawang merah. Jawaban responden sebanyak 23 responden menjawab sangat setuju, 6 responden menjawab setuju, 7 responden menjawab ragu-ragu, dan tidak ada responden yang menjawab tidak setuju dan sangat tidak setuju. Nilai skor rata-rata sebesar 4,44, artinya responden setuju dengan adanya program PMUK di Desa Ceurucok dapat 
meningkatkan skala usahatani bawang merah yang dikelolanya. Peningkatan skala usahatani sebaiknya diikuti dengan efisiensi penggunaan faktor produksi.

Berdasarkan kelima indikator variabel pelaksanaan Program PMUK dapat dikatakan bahwa responden setuju dengan program PMUK yang telah dijalankan selama ini.

\section{Pemberdayaan Petani Bawang Merah}

Indikator pemberdayaan petani dalam penelitian ini dilihat berdasarkan lima indikator variabel yaitu: (1) Adanya akses permodalan sesuai kebutuhan usahatani; (2) Bimbingan teknik budidaya dari penyuluh; (3) teknik budidaya bawang merah lebih intensif; (4) mendapatkan pelatihan budidaya bawang merah sesuai anjuran; dan (5) penerapan teknologi baru. Rekapitulasi jawaban responden tentang pemberdayaan petani dapat dilihat pada tabel berikut.

Tabel 10. Rekapitulasi Jawaban Responden tentang Pemberdayaan Petani

\begin{tabular}{|c|c|c|c|c|c|c|c|}
\hline No & Pertanyaan & SS & S & $\mathrm{R}$ & TS & STS & $\begin{array}{l}\text { Rata- } \\
\text { Rata }\end{array}$ \\
\hline 1 & $\begin{array}{l}\text { Responden memperoleh tambahan } \\
\text { modal usahatani sesuai kebutuhan. }\end{array}$ & $\begin{array}{c}16 \\
(80)\end{array}$ & $\begin{array}{c}11 \\
(44)\end{array}$ & $\begin{array}{c}6 \\
(18)\end{array}$ & $\begin{array}{l}3 \\
(6)\end{array}$ & & 4,11 \\
\hline 2 & $\begin{array}{l}\text { Responden memperoleh bimbingan } \\
\text { teknik budidaya dari petugas terkait } \\
\text { (BPP). }\end{array}$ & $\begin{array}{c}11 \\
(55)\end{array}$ & $\begin{array}{c}12 \\
(48)\end{array}$ & $\begin{array}{c}13 \\
(39)\end{array}$ & & & 3,94 \\
\hline 3 & $\begin{array}{l}\text { Teknik budidaya bawang merah } \\
\text { lebih intensif dilakukan sejak adanya } \\
\text { bantuan PMUK. }\end{array}$ & $\begin{array}{c}11 \\
(55)\end{array}$ & $\begin{array}{c}21 \\
(84)\end{array}$ & \begin{tabular}{c|c}
2 \\
$(6)$
\end{tabular} & $\begin{array}{l}2 \\
(4)\end{array}$ & & 4,14 \\
\hline 4 & $\begin{array}{l}\text { Responden memperoleh pelatihan } \\
\text { tentang teknik budidaya bawang } \\
\text { merah. }\end{array}$ & $\begin{array}{c}8 \\
(40)\end{array}$ & $\begin{array}{c}23 \\
(92)\end{array}$ & $\begin{array}{c}5 \\
(15)\end{array}$ & & & 4,08 \\
\hline 5 & $\begin{array}{l}\text { Responden menerapkan teknologi } \\
\text { baru dalam budidaya bawang merah }\end{array}$ & $\begin{array}{c}10 \\
(50)\end{array}$ & $\begin{array}{c}21 \\
(84)\end{array}$ & \begin{tabular}{|c|}
5 \\
$(15)$
\end{tabular} & & & 4,14 \\
\hline
\end{tabular}

Sumber: data primer, diolah, 2017.

Pada tabel di atas dapat dijelaskan bahwa indikator pertama, akses permodalan sesuai kebutuhan usahatani, sebanyak 16 responden menjawab sangat setuju, 11 responden menjawab setuju, 6 responden menjawab raguragu, 3 responden menjawab tidak setuju, dan tidak ada responden yang menjawab tidak setuju. Nilai skor rata-rata sebesar 4,11 , hal ini berarti responden setuju program PMUK membantu akses responden terhadap modal usaha.

Indikator kedua, memperoleh bimbingan teknik budidaya dari penyuluh sebanyak 11 responden menjawab sangat setuju, 12 responden menjawab setuju, 13 responden menjawab ragu-ragu, dan tidak ada responden yang menjawab tidak setuju dan sangat tidak setuju. Nilai skor rata-rata sebesar 3,94, hal ini berarti responden setuju bahwa mereka memperoleh pemberdayaan dalam aspek teknik budidaya bawang merah. Teknik budidaya yang diajarkan antara lain pemilihan bibit unggul, penggunaan pupuk organik pada lahan tanam, penggunaan pupuk pelengkap cair, pengendalian hama penyakit dan panen serta pasca panen bawang merah.

Indikator ketiga budidaya tanaman bawang merah dilakukan lebih intensif, sebanyak 11 responden menjawab sangat setuju, 21 responden menjawab setuju, 2 responden menjawab ragu-ragu, 2 responden menjawab tidak setuju, dan tidak ada responden yang menjawab tidak setuju. Nilai skor rata-rata sebesar 4,14, yang berarti responden setuju melalui program PMUK budidaya tanaman dilakukan lebih intensif. Intensifikasi budidaya tanaman bawang merah dilakukan melalui penggunaan bibit unggul, pengaturan jarak tanam, pemupukan berimbang, pengendalian hama penyakit secara terpadu, penanganan panen dan pasca panen, serta rencana pemasaran dari komoditi yang dihasilkan.

Indikator keempat, responden diberikan pelatihan tentang teknik budidaya bawang merah, sebanyak 8 responden menjawab sangat setuju, 23 responden menjawab setuju, 5 responden menjawab ragu-ragu, dan tidak ada responden yang menjawab tidak setuju dan sangat tidak setuju. Nilai skor rata-rata sebesar 4,08 , yang berarti responden menyatakan setuju ada pelatihan teknik budidaya. Pelatihan dilaksanakan di tingkat gapoktan (gabungan kelompok tani), adapun narasumber berasal dari dinas terkait. Penyelenggaraan pelatihan bertujuan untuk meningkatkan kemampuan dan keterampilan petani dalam hal teknik budidaya, khususnya tanaman bawang merah.

Indikator kelima, menerapkan teknologi baru dalam budidaya sebanyak 10 responden menjawab sangat setuju, 21 responden menjawab setuju, 5 responden menjawab raguragu, dan tidak ada responden yang menjawab tidak setuju dan sangat tidak setuju. Nilai skor rata-rata sebesar 4,14, yang berarti responden setuju adanya pemberdayaan dalam hal penerapan teknologi baru. Penerapan teknologi berupa penggunaan mulsa organik dan anorganik, penggunaan benih, dan penggunaan pupuk hayati. 
Berdasarkan kelima indikator variabel pemberdayaan petani dapat dikatakan bahwa responden setuju dengan program PMUK telah dilakukan pemberdayaan petani bawang merah. Pemberdayaan petani pada dasarnya adalah meningkatkan keterampilan petani dalam hal budidaya tanaman bawang merah sehingga usahatani yang dikelolanya efisien.

Soekartawi (2002) menjelaskan bahwa tersedianya sarana atau faktor produksi (input) belum berarti produktifitas yang diperoleh petani akan tinggi. Namun bagaiman petani melakukan usahanya secara efisien adalah upaya yang sangat penting. Efisiensi teknis akan tercapai bila petani mampu mengalokasikan faktor produksi sedemikian rupa sehingga produksi tinggi tercapai. Bila petani mendapat keuntungan besar dalam usahataninnya dikatakan bahwa alokasi faktor produksi efisien secara alokatif. Cara ini dapat ditempuh dengan membeli faktor produksi pada harga murah dan menjual hasil pada harga relatif tinggi. Bila petani mampu meningkatkan produksinya dengan harga sarana produksi dapat ditekan tetapi harga jual tinggi, maka petani tersebut melakukan efisiensi teknis dan efisiensi harga atau melakukan efisiensi ekonomi.

\section{Analisis Pemberdayaan Petani Bawang Merah melalui PMUK}

Pemberdayaan petani dilakukan untuk memfasilitasi petani agar mampu: 1) menganalisis situasi perikehidupan dan masalahmasalahnya; 2) mencari pemecahan masalah berdasarkan kemampuan dan keterbatasan yang mereka miliki; 3) mengembangkan usahanya dengan segala kemampuan dan sumberdaya yang dimiliki sendiri; 4) mengembangkan sistem untuk mengakses sumberdaya yang diperlukan. Pada intinya petani adalah pengambil keputusan pada setiap kegiatan yang akan mereka lakukan.

Analisis pemberdayaan petani melalui program PMUK dilakukan berdasarkan indikator masing-masing variabel. Analisis data menggunakan program SPSS (Statistical Product and Service Solution) versi 16.0. Hasil analisis dinyatakan dalam bentuk persamaan regresi linear sederhana yaitu :

$\mathrm{Y}=\mathrm{a}+\mathrm{bX}$,

dimana:

$\mathrm{Y} \quad=$ Variabel pemberdayaan petani,

$\mathrm{X}=$ Variabel program PMUK,

a = Konstanta atau intersep,

$\mathrm{b}=$ Koefisien variabel program PMUK.
Hasil analisa data menghasilkan model estimasi persamaan regresi sebagai berikut :

$\mathrm{Y}=0,495+0,964 \mathrm{X}$

Model persamaan regresi yang dihasilkan menunjukkan variabel program PMUK mempunyai pengaruh positif terhadap pemberdayaan petani di Desa Ceurucok Sagoe Kecamatan Simpang Tiga dengan koefisien sebesar 0,964. Artinya, pelaksanaan program PMUK sebesar 1 satuan akan meningkatkan pemberdayaan petani sebesar 0,964 satuan.

Selanjutnya, untuk mengetahui sejauh mana kemampuan variabel program PMUK dapat menjelaskan variabel pemberdayaan petani digunakan koefisien determinasi (R2). Pada Lampiran 2 diperoleh nilai R2 sebesar 0,528 yang artinya variabel $\mathrm{X}$ mempengaruhi variabel dependen sebesar $52,80 \%$, sedangkan sisanya sebesar 47,20\% dijelaskan oleh variabel lain yang tidak dimasukkan kedalam model estimasi ini.

Terhadap model estimasi yang diperoleh dilakukan uji $\mathrm{t}$ untuk mengetahui signifikansi pengaruh variabel program PMUK terhadap variabel pemberdayaan petani. Uji $\mathrm{t}$ dihitung sebagai berikut :

t ratio $=\frac{b}{\operatorname{Se}(b)}=\frac{0,964}{0,156}=6,17$

Nilai t hitung diperoleh sebesar 6,17. Kemudian, nilai t hitung dibandingkan dengan nilai t tabel pada tingkat kepercayaan $95 \%$ dan discount factor $(\mathrm{df}=2) . \mathrm{t} 1 / 2 \alpha=0.025, \mathrm{t}$ tabel $(\mathrm{df}=34)=2.028$. Nilai $t$ hitung $>t$ tabel artinya variabel $\mathrm{X}$ (program PMUK) mempunyai pengaruh yang signifikan terhadap peningkatan pemberdayaan petani bawang merah dengan tingkat kepercayaan $95 \%$.

\section{KESIMPULAN DAN SARAN \\ Kesimpulan}

Program PMUK mempunyai pengaruh signifikan terhadap pemberdayaan petani bawang merah di Desa Ceurucok Sagoe Kecamatan Simpang Tiga dengan koefisien variabel sebesar 0,964. Koefisien determinasi sebesar 52,80 \% dan nilai t hitung sebesar 6,17.

\section{Saran}

Dari hasil penelitian ini dapat dikemukakan beberapa saran sebagai berikut: agar program PMUK dapat berkelanjutan, maka penerapan sanksi yang tegas bagi anggota yang menunggak pembayaran sebaiknya diatur dalam 
Anggaran Dasar/Anggaran Rumah Tangga kelompok.

\section{DAFTAR PUSTAKA}

Azwar, S. 2005. Metode Penelitian. Pustaka Pelajar. Yogyakarta.

Badan Pusat Statistik. 2015. Diakses dari http://www.bps.go.id/. Pada tanggal 19 November 2016.

Dinas Pertanian. 2007. Penyusunan Road Map Komoditas Unggulan Perkebunan (KopiArabika) Kabupaten Karangasem. Karangasem: Dinas Pertanian, Perkebunan dan Perhutanan Kabupaten Karangasem.

Hapsoh dan Hasanah, Y. (2011). Budidaya Tanaman Obat dan Rempah. USU Press. Medan.

Hernanto, F. 2008. Ilmu Usahatani. Penebar Swadaya. Jakarta.

Irianto, A. 2004. Statistika Konsep, Dasar, Aplikasi, dan Pengembangannya. Kencana Prenada Media Group. Jakarta.

Kadariah. 1994. Teori Ekonomi Mikro. Fakultas Ekonomi Universitas Indonesia. Jakarta.
Payne, M. 2007. Modern Social Work Theory: Second Edition. London.

Rahayu, E dan Berlian Nur. 2004. Bawang Merah, Cet:X. Penebar Swadaya. Jakarta.

Rukmana, R. 1995. Bawang Merah Budidaya Dan Pengolahan Pasca Panen. Kanisius, Jakarta.

Setijo. 2003. Benih Bawang Merah. Kanisius. Yogyakarta.

Sihombing, U. (2004). Pengaruh Keterlibatan Dalam Pengambilan Keputusan. Penilaian Pada Lingkungan Kerja dan Motivasi Berprestasi Terhadap Kepuasan Kerja Pamong Praja. http://www.dupdiknas.go.id, [30 November 2012].

Wibowo, S. 1999. Budidaya Bawang Putih, Merah dan Bombay. Penebar Swadaya. Jakarta.

Vitayala, A. 2000. Suatu Pikiran tentang Kebijakan Pemberdayaan Kelembagaan Tani. Deptanhut. Jakarta. 